\title{
Slavarna på Timor \\ Ofrihet och förnedring i en tidig kolonial miljö
}

\section{Hans Hägerdal}

Slaveriets historia är inte helt oskriven, och i skrivande stund utges ett ambitiöst och världstäckande arbete som skildrar företeelsen från urtid till nutid. ${ }^{1}$ Däremot är det tydligt att mycket av litteraturen om denna mörka sida av mänskligheten har kommit att koncentrera sig på den transatlantiska slavhandeln och det amerikanska slaveriet. Rikedomen av dokument på ett tillgängligt språk (engelska) har givit slaveriets historiografi en västlig tyngdpunkt. På senare år har forskningen dock börjat se utvecklingen i den atlantiska världen i ett större perspektiv. Man har studerat de afrikanska samhällen varifrån slavarbetskraften togs och sedermera skeppades över till den nya världen och pekat på att den transatlantiska slavhandeln bara var en del av de stora handelsstråk där kommersen med mänskligt kött och blod pågick. ${ }^{2}$ Mycket av den afrikanska slavhandeln hade föga eller intet med den vite mannens framfart att skaffa utan gick till Nordafrika eller till de västra och södra delarna av Asien.

Hanteringen av asiatiska slavar har inte varit lika grundligt utforskad. Med tanke på den oerhörda västerländska lärdom som ägnats åt snart sagt varje aspekt av kinesisk kultur och historia, finns det förvånansvärt lite gjort om den ofrihet som belastade mängder av människor över seklernas lopp. Ungefär samma sak gäller för Indiens del. Något bättre är situationen för Sydöstasien, den väldiga region som ligger söder om Kina och öster om Indien. Här har faktiskt forskningen kommit med viktiga bidrag under de senaste decennierna. ${ }^{3}$ Västerländska kolonisatörer nådde Sydöstasien redan på 1500-talet, och från början av 1600-talet opererade mäktiga handelskompanier i området. För de europeiska handlarna var det väsentligt att föra bok över det som köptes och såldes. Rapporter och räkenskaper från en handelspost kopierades och skickades till huvudkontoret där man gjorde sina handelsstrategiska drag utifrån det man läste. I jämförelse med de inhemska sydöstasiatiska rikena har vi därför ett solitt europeiskt material om de kommoditeter man handlade med - även levande sådana. I föreliggande studie kommer jag att utnyttja sådant arkivmaterial för att belysa hur handeln och hanteringen av slavar utformades i skärningsfältet mellan ett kolonialt och ett inhemskt samfund. Jag kommer först att diskutera de mer allmänna sydöstasiatiska förhållandena, och därefter fokusera på ön Timor.

1 Det gäller D. Harrison, Slaveri; En världshistoria om ofrihet, Del 1. Lund: Historiska Media 2006; ytterligare 2 delar är projekterade.

2 P. E. Lovejoy, 'Identifying enslaved Africans in the African diaspora', i P. E. Lovejoy [red.], Identity in the Shadow of Slavery. London \& New York: Continuum 2000, s. 1-29.

3 Se särskilt A. Reid [red.], Slavery, Bondage and Dependency in Southeast Asia (St. Lucia: University of Queensland press 1983), och J. F. Warren, The Sulu Zone: The Dynamics of External Trade, Slavery, and Ethnicity in the Transformation of a Southeast Asian Maritime State. Singapore: Singapore University Press 1981. 


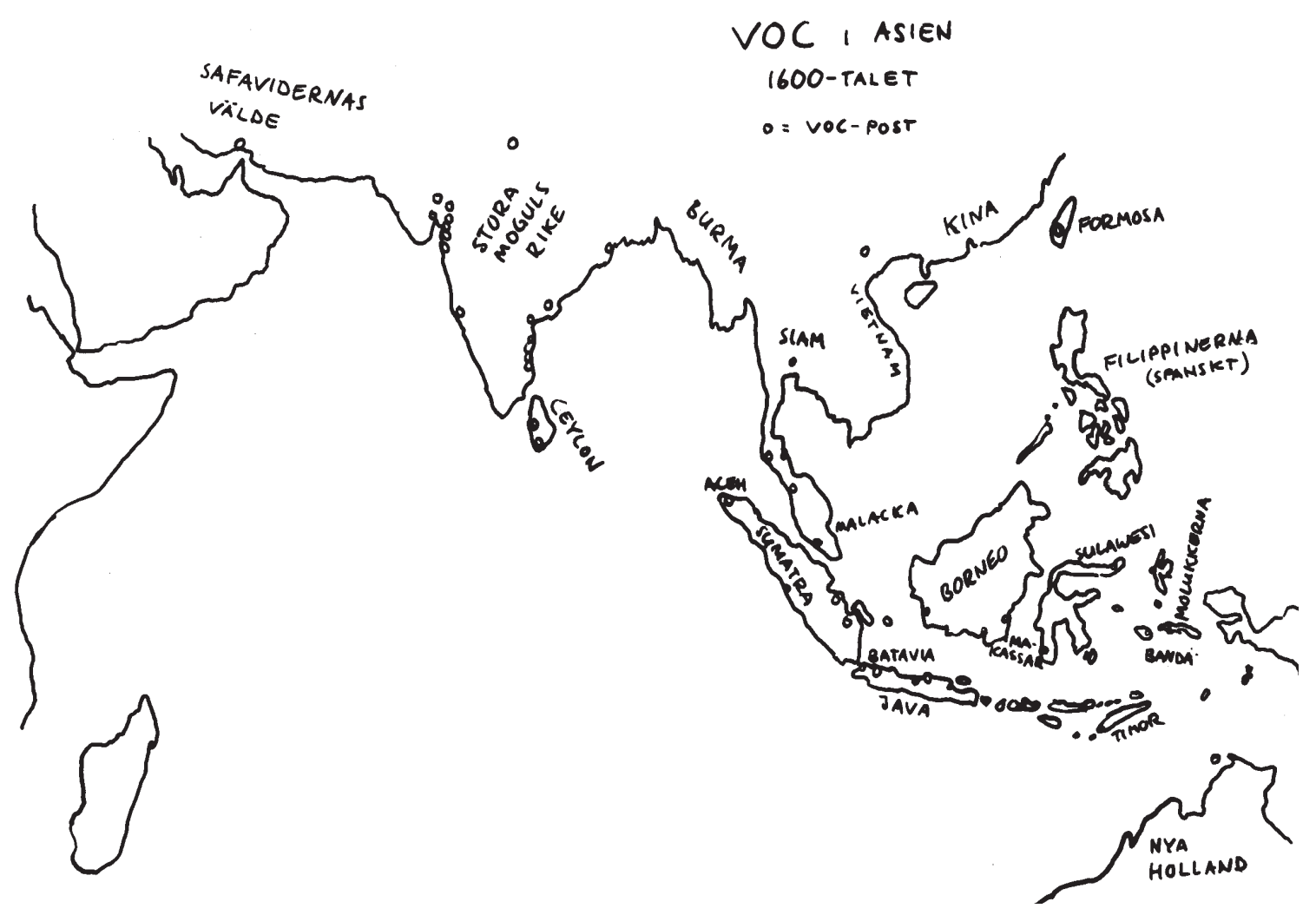

I 1600-talets Sydöstasien hade kungarikena på fastlandet en sådan storlek och stadga att de utan större besvär kunde motstå europeisk aggression. Länder som Siam, Kambodja och Vietnam fick mer än en gång ovälkommen påhälsning av kanonbestyckade fartyg och muskötbeväpnade vita trupper, men stod än så länge rycken. Det var först långt in på 1800-talet som den västerländska teknologiska utvecklingen började ta ut sin rätt och lägga de flesta av de här länderna under den vite mannens svärd. I den vidsträckta tropiska övärlden, det som idag är Malaysia, Filippinerna, Indonesien och Östtimor, var situationen mycket annorlunda. Kungarikena var mindre och ibland höjde sig inte organisationen över hövdingadömenas eller stamsamhällenas nivå. Dessutom utgjorde övärlden ett gammalt handelsstråk där kinesiska, indiska och muslimska sjöfarare sedan länge opererade och ibland skaffade sig politiskt inflytande. Här hade en främmande inkräktare betydligt bättre chanser att göra sin vilja gällande.

I denna färgrika värld kom de kalvinistiska handelsmännen från Nederländerna att dra längsta strået i kampen om marknader. Det holländska Ostindiska kompaniet eller VOC (Vereenigde Oost-Indische Compagnie) grundades 1602 som ett av de första egentliga aktiebolagen, dock med betydligt mindre demokratiska strukturer än dagens aktiebolag. ${ }^{4}$ Verksamheten leddes formellt av ett råd, De sjutton herrarna, som hade sitt säte i Amsterdam och representerade olika delar av landet. Vanliga holländare kunde investera en summa i kompaniet och kunde efter ett visst antal år ta ut sin andel på vinst eller förlust. VOC var

4 Jag använder i denna artikel uttrycket holländare snarare än det formellt sett riktigare nederländare. Såväl europeiska rivaler som inhemska folkgrupper i Sydöstasien använde uttryck motsvarande holländare (walanda, belanda etc.) för att beteckna VOC:s manskap. Själva betecknade de sig omväxlande som Hollands, Nederlands eller Duits (tysk, jfr Dutch). 
tillförsäkrat monopol på den holländska handeln öster om Godahoppsudden, under det att ett särskilt västindiskt kompani (WIC) hade motsvarande monopol i väster. ${ }^{5}$ Som ett led i rivaliteten med portugiser och spanjorer och så småningom engelsmän bet sig kompaniet fast i befästa stödjepunkter. I början hade holländarna sitt främsta tillhåll i de legendomspunna kryddöarna i östra Indonesien. Snart fann de det dock mer praktiskt att inrätta ett allmänt rendezvous i närheten av de stora sjörutterna längre åt väster. Efter 1619 residerade VOC i Batavia på Javas nordkust, det som idag är megastaden Jakarta. Här befann sig generalguvernören med sitt råd. Till Europa var det lång väg och generalguvernören hade stora befogenheter att börja krig och sluta allianser som han och hans råd fann lämpligast. På sätt och vis kan man därför se VOC som en asiatisk makt likväl som en europeisk. Det fanns dock en viktig skillnad mellan ett regionalt kungarike och ett handelskompani. Med sin aktiemarknad och kreditsystem, sitt spridda ägande och sina fasta regler, stod ett handelskompani i skarp kontrast mot det mindre organiserade och mer nyckfulla sätt som makten hanterades på i ett sydöstasiatiskt rike. ${ }^{6}$

Krig var förvisso vad kompaniet förde. Visserligen var holländarna intresserade av att handla snarare än att lägga sig i den oöverskådligt komplicerade politiken i övärlden. Men i och med att kompaniet upprättade fler och fler handelsstationer och fort i Asiens kusttrakter fick det allt större besvär med att säkra handelsrutterna och se till att inga fiender hotade utposterna. Då man ser det på en karta förstår man vad det var fråga om. Något femtiotal utposter kantade det maritima Asien, med stark koncentration till det som idag är Indonesien. ${ }^{7}$ Därtill hade VOC sina europeiska fiender att nappas med. Med England fördes ett oförklarat krig på 1610- och 1620-talen, till holländarnas fördel, och med portugiserna hade man periodvis återkommande fejder fram till dess att fred slöts år 1663. ${ }^{8}$ Mot spanjorerna, som sedan länge behärskade Filippinerna, kunde inte VOC göra så mycket.

Mot slutet av 1600-talet kan man säga att VOC hade nått sin höjdpunkt. De viktigaste kungarikena i den sydöstasiatiska övärlden krossades eller försvagades målmedvetet $i$ andra hälften av seklet. De ledande folkslagen i övärlden var muslimer, men det var ingenting som nämnvärt hotade de kalvinistiska handlarnas ställning. En och annan lokal entusiast föreslog visserligen att man borde proklamera jihad mot de otrogna främlingarna men de fann föga gensvar. I motsats till portugiserna och spanjorerna var holländarna inte speciellt intresserade av att omvända lokala folkslag till kristendomen. Högtidliga eder svors praktiskt nog med handen på både bibeln och koranen. Kompaniet styrde dessutom bara begränsade områden som direkta besittningar. I övrigt byggde de upp ett allianssystem där deras förbundna lovade att avhålla sig från varje otillåten kontakt med andra europeiska makter. Med brutala medel utvecklade kompaniet ett monopolsystem där en rad grödor och andra produkter endast fick höstas in av holländska intressenter. Mycket av den gamla sydöstasiatiska handeln förstör-

5 L. Akveld \& E. M. Jacobs, The Colourful World of the VOC. Amsterdam: THOTH 2002, s. 12-15.

6 A. Reid, Southeast Asia in the Age of Commerce, Vol 2. New Haven: Yale 1993, s. 131.

7 R. Cribb, Historical Atlas of Indonesia. Richmond: Curzon 2000, s. 106-107.

8 G. Milton, Muskotkriget: Kampen om de ostidiska kryddöarnat. Lund: Historiska Media 2003; E. van Veen, 'The European-Asian relations during the 16th and 17th centuries in a global perspective', in E. van Veen \& L. Blussé [red.], Rivalry and Conflict: European Traders and Asian Trading Networks in the $16^{\text {th }}$ and $17^{\text {th }}$ Centuries. Leiden: CNWS Publications 2005, s. 19. 
des vilket är en viktig förklaring till den underutveckling som regionen fortfarande lider av - dock inte den enda. ${ }^{9}$

De produkter som VOC intresserade sig för var av mycket skiftande slag. Det som till en början lockade var de värdefulla kryddorna, det som en gång i tiden eggat de portugisiska sjöfararna i deras färder österut. Peppar, nejlikor och muskotnötter var dock bara början. VOC utforskade systematiskt de möjligheter till handel som fanns öster om Godahoppsudden och började ta del i den omfattande handel som redan förekom mellan olika delar av Asien. Det gällde så skilda artiklar som ris, indigo, dyrbara trädslag, guld, tenn, kamfer, fågelbon, textilier, elfenben och opium. Vidare fanns det europeiska tekniska och lyxbetonade artiklar som efterfrågades av många asiatiska aristokrater. Och sist men inte minst handlade kompaniet med slavar.

Slaveriet var verkligen inget europeiskt påfund. Tvärtom fanns sedan urminnes tider former av ofrihet i de asiatiska samhällena. Slavar omtalas i Kina sedan åtminstone Zhoudynastin (ca 1045-256 f.Kr.) och i Indien sedan andra årtusendet f.Kr. I Sydöstasien dyker de upp med de tidiga utförliga källorna i slutet av första årtusendet e.Kr., inte minst i egenskap av tempelslavar. Liksom i resten av världen rådde stora skillnader mellan olika typer av ofria. I Kina var ofriheten för det mesta en följd av oförmåga att försörja sig eller betala skulder, men krigiska konflikter ledde också med jämna mellanrum till massförslavning av befolkningar. Import av utländska slavar var inte lika vanlig men förekom under vissa perioder - ända från Afrika hämtades svarta slavar som en exotisk kuriositet. Även om bara någon procent av den kinesiska befolkningen var ofri betydde det fortfarande ett stort antal. I Indien fanns efter 1100-talet en religiös aspekt på slavfrågan: den härskande gruppen i Nordindien var muslimsk, vilket enligt gällande islamsk rätt betydde att personer ur den hinduiska majoritetsbefolkningen kunde hållas som slavar. Liksom i Kina rörde det sig knappast om något storskaligt jordbruksslaveri, utan snarare om hushållsslavar. Dessutom förekom en import av slavsoldater från bland annat Afrika; dessa kunde nå höga positioner i samhället. ${ }^{10}$

I Sydöstasien, såsom det träder fram i materialet på 1600- och 1700-talen, var slaveri en självklarhet som ingen ifrågasatte. Det hänger nära samman med att kontroll över människor strängt taget var mycket viktigare än kontrollen av jord. Dagens Sydöstasien präglas av överbefolkning, men på 1600-talet var det mesta av området mycket glest bebott. Med undantag för vissa plättar, som Röda flodens slättland i norra Vietnam, var jord ingen bristvara. Det fanns knappast något klart juridiskt system för ägande av jord, utan marken räknades ofta som knuten till den som brukade den. För en sydöstasiatisk furste eller storman var det därför viktigast att man hade kontroll över så många människor som möjligt, eftersom marken inte odlade sig själv. Det fanns dessutom en trygghetsaspekt $i$ att ha många människor under sitt omedelbara välde.

I de otaliga små riken och hövdingadömen som fanns i Sydöstasiens övärld rådde inte alltid lag och ordning. Rättsväsendet var inte speciellt utvecklat, furstemakten grep inte mer än nödvändigt in i lokalsamhället, och småkrig och piratverksamhet ökade osäkerheten. Under de förhållandena kunde ofrihet vara ett alternativ även ur den ofries synvinkel. Upplys9 Reid, Southeast Asia in the Age of Commerce, Vol. 2, s. 270-281, 285-291, 299-303.

10 Harrison, Slaveri, s. 413-51. 
ningsfilosofen Montesquieu skrev 1748 på grundval av europeiska reseberättelser: 'I Achem [Aceh på Sumatra] vill var och en sälja sig själv. En del storherrar har inte mindre än tusen slavar [...] Detta är det sanna och rationella ursprunget till den milda slaverilag som finns i en del länder; och mild må den vara, då den är baserad på en mans fria val av sin herre, till hans egen fördel; något som utgör en ömsesidig konvention mellan de bägge parterna."11 Citatet antyder nödvändigheten av att skilja mellan ofria och ofria. Det förekom former av personligt beroende. Mer avhängiga av fritt val än av tvång, där patron och klient behövde varandras beskydd och stöd. Det förekom också betydligt hårdare former av slaveri där människor kunde köpas och säljas som boskap. Gränsen mellan vad som i egentlig mening var slav och icke-slav var tämligen porös och flytande.

Slav kunde man bli på åtminstone fem olika sätt. De äldre sydöstasiatiska lagtexterna talar om:

1) arv av ofriheten från sina föräldrar

2) försäljning som slav av släktingar (eller frivilligt, av en själv)

3) fångenskap som följd av krig

4) juridiskt dömande som slav

5) oförmåga att betala skulder.

Det sistnämnda anses ha varit den klart viktigaste orsaken till att människor miste sin personliga frihet. ${ }^{12}$ Under den tredje punkten kan man lägga till att det inte bara var så att slavar togs som en sidoeffekt av krigshandlingar. Det förekom också rena slavräder som kunde vara organiserade på en löpande basis. Folkgruppen ilanun i södra Filippinerna specialiserade sig på att genomföra räder i arkipelagen under sent 1700-tal och tidigt 1800-tal och drog sig inte för att göra tillfångatagna européer till slavar. ${ }^{13}$

Det holländska kompaniet insåg snabbt de ekonomiska fördelarna med den slavhandel som redan var så fast etablerad. Lika lite som islam hade den tidens kristendom någonting emot slaveriet som princip. I bägge religionerna ansågs det olämpligt att ta trosfränder som slavar men i praktiken bröts ofta denna princip. De muslimska ilanun tvekade till exempel inte att angripa muslimska kustfolk på Sumatra. Med sin stora handelsflotta och sin organisation kunde VOC istället föra upp slavhandeln till oanade nivåer. Den stora skillnaden mellan det gamla sydöstasiatiska och det nya holländska slaveriet var just att det senare var ett slags "rationell" och opersonlig hantering som för det mesta saknade den personliga bindning som funnits i det gamla systemet. ${ }^{14}$

Med undantag för den lilla ögruppen Banda i Moluckerna användes slavarna inte i arbetet med att odla grödor, eftersom det var mer rationellt att låta fria (men beroende) bönder sköta den saken. I stället var det i städerna som arbetskraften behövdes. I VOC:s handelsposter,

11 A. Reid, Southeast Asia in the Age of Commerce, Vol. 1. New Haven: Yale University Press 1988, s. 129.

12 Ibid, s. 131.

13 R. Vos, Gentle Janus, Merchant Prince: The VOC and the Tightrope of Diplomacy in the Malay World, 1740-1800. Leiden: KITLV Press 1993, s. 182-183.

14 J. P. Rodriguez [red.], The Historical Encyclopedia of World Slavery, Vol. I. Santa Barbara: ABCClio 1997, s. 366. 
framför allt Batavia, fanns det ett stort behov av arbetskraft som man kunde kontrollera - runt 1770 handlade holländarna med så mycket som 4000 slavar om året. ${ }^{15}$ Men även städer i övärlden som inte beboddes av européer, som Banda Aceh och Banten, ropade efter slavar. Städernas burgna invånare behövde tjänare i hushållen, byggarbetare och kulier (grovarbetare). För slavar som hamnade i en sådan urban miljö fanns det vissa möjligheter att avancera socialt och så småningom bli frigiven, och de nyankomna slavarna fick vanligen de nedrigaste sysslorna. Villkoren skilde sig mycket mellan krigsfångar, som var nästan rättslösa, och arbetsslavar som kunde vara högt värderade för sin yrkesskicklighet. ${ }^{16}$ Men VOC:s bestämmelser var hårda när en ofri person av endera sorten hade begått en förseelse; de uppstudsiga utsattes för grymma straff som röjer den osäkerhet holländarna kände inför den stora och potentiellt rebelliska skaran av ofria.

De viktigaste av de områden i övärlden som lämnade slavar var Bali och södra Sulawesi. ${ }^{17}$ Andra grupper som på frivillig eller ofrivillig väg lämnade ut sina söner och döttrar var bland annat batakerna i norra Sumatra och papuanena i västra Nya Guinea. Det tenderade att röra sig om folkslag som vid den här tiden varken var kristna eller muslimer. Man har beräknat att 150000 slavar fördes ut från den lilla men tättbefolkade ön Bali under perioden 1650-1830 - människor som väl att märka inte infångats i slavräder utan genom krig eller skuldsättning tagits av lokala furstar och sålts vidare till holländarna. ${ }^{18}$ Det fanns med andra ord inga skrupler mot att sälja stamfränder när inte religiösa skäl låg i vägen och skruplerna infann sig ofta inte ens då.

Jag kommer nu att gå ner på mikronivå för att studera hur det sydöstasiatiska slaveriet kunde fungera $\mathrm{i}$ en kontext som var påfallande lokal men samtidigt påverkad av VOC:s verksamhet. Den plats som studeras är Timor i östra delen av den sydöstasiatiska övärlden - namnet betyder just "Östern" på malajiska. Trots att Timor ingalunda är en liten ö utan motsvarar Nederländerna i yta, låg det utanför de sydöstasiatiska allfartsvägarna. Ön är torrrare än på de flesta håll i regionen, och det inre består av otillgängliga berg och högländer. Medan inlandet är förhållandevis svalt råder en påfrestande värme vid kusten, det vill säga den del som främmande sjöfarare kunde förväntas besöka. Det är ett förhållande som lämnat åtskilliga svavelosande beskrivningar efter sig i reselitteraturen, och många europeiska kolonialtjänstemän hade blott alltför bråttom att komma därifrån. Den timoresiska febern (Timorese koortsen) var en fruktad dråpare bland de fåtaliga vita bosättarna. ${ }^{19}$

Att Timor hade sina attraktioner framgår dock av de tidigaste reseberättelserna. Den kinesiske skriftställaren Wang Dayuan författade i mitten av 1300-talet en geografisk text med titeln Dao yi Zhi lue där han hade följande att förtälja.

15 M. D. Poesponegoro \& N. Notosusanto, Sejarah Nasional Indonesia, Vol. III. Jakarta: Balai Pustaka 1993, s. 264.

16 Cribb, Historical Atlas of Indonesia, s. 53.

17 Poesponegoro \& Notosuanto, Sejarah Nasional Indonesia, s. 263-264.

18 H. Schulte Nordholt, The Spell of Power: A History of Balinese Politics, 1650-1940. Leiden: KITLV Press 1996, s. 41.

19 För en diskussion av Timors geografiska förhållanden, se F. J. Ormeling, The Timor Problem: A Geographical Interpretation of an Underdeveloped Island. Groningen: Wolters 1956, särskilt s. 13-29. 


\section{TIMORREGIONEN}

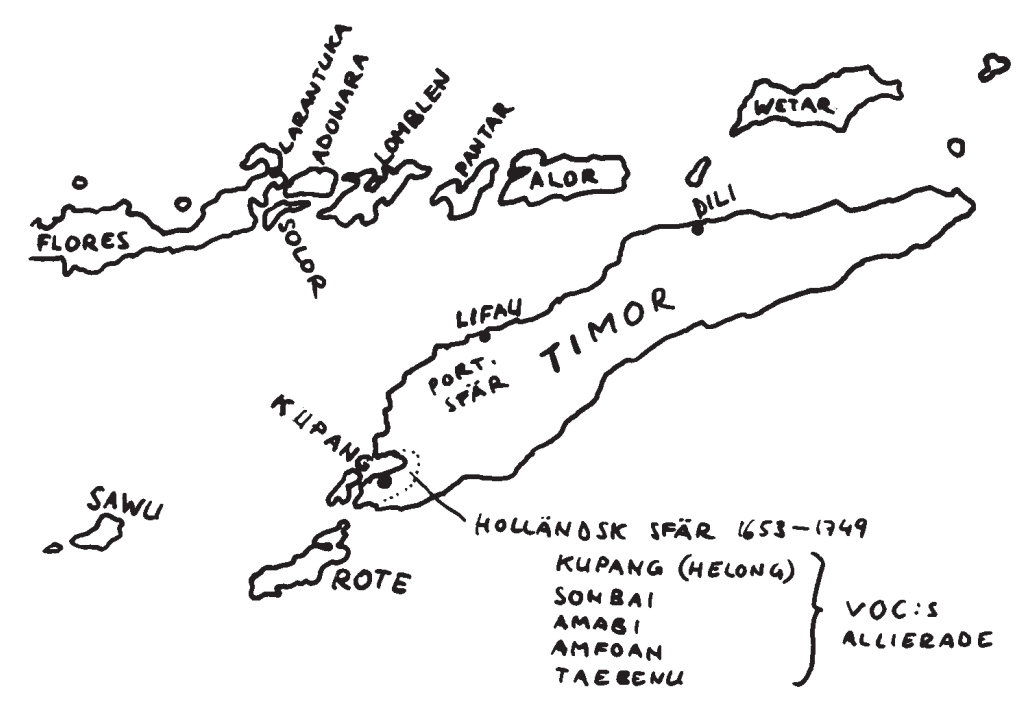

Bland öns berg växer inga andra träd än sandel som är ytterst rikligt förekommande. Det handlas upp i utbyte mot silver, järn, porslinskoppar, kläde från västliga länder och färgat taft. Sammantaget finns tolv platser som kallas hamnar. Där finns en lokal hövding. Klimatet är oregelbundet, hett på dagen, svalt på natten. Infödingarnas sedvänjor är obscena. Män och kvinnor klipper håret och bär korta bommullskjortlar. De binder dem runt höften med kläde från Champa. Marknadspriserna på alkohol och kött är resonabla. Kvinnorna är skamlösa. Stamhövdingarna tycker om mat, vin och sex, och när de sover täcker de sig inte så att de som infekteras mestadels avlider. Om man har varit oförsiktig bland infödingarna kommer sjukdomen att bryta ut med attacker av hög feber då skeppet återvänt till Kina. ${ }^{20}$

Beståndsdelarna i denna något fördomsfulla redogörelse kommer igen i senare europeiska berättelser. De bästa sydöstasiatiska bestånden av sandelträ fanns på Timor, även om idén att hela ön var täckt av dem visade sig vara minst sagt överdriven. Sandel (santalum album) är ett väldoftande träslag som med fördel kan användas för hantverksprodukter, oljor och rökelse. För kineserna, som behövde rökelse för tempelceremonier, var den timoresiska sandeln åtråvärd. Vidare var Timor ett lågteknologiskt samhälle där metallföremål, avancerad keramik m.m. fick importeras. Befolkningen var tydligt skiktad i en aristokratisk, en friboren och en slavklass, men de lokala furstarna härskade över ganska små områden, vilket betydde att besökare inte besvärades av en handfast centralmakt. ${ }^{21}$ För den som klarade av de svårnavigerade vattnen runt Timor fanns alltså vinster att hämta.

Då portugiserna anlänt till Sydöstasien 1509 fick de snart korn på detta. Duarte Barbosa sammanställde ett värdefullt geografiskt arbete ca 1516. Här nämns för första gången slavar som en timoresisk handelsvara, och han skrev följande:

20 R. Ptak, 'Some references to Timor in old Chinese records', Ming Studies 17 1983, s. 37.

21 A. T. de Matos, Timor Português, 1515-1769. Lisboa: Instituto Histórico Infante Dom Henrique 1974, s. 189-191; A. de Castro, As possessões portuguezas na Oceania. Lisboa: Imprensa Nacional 1867, s. 201. 
På denna ö finns mycket vit sandel vilka morerna värderar högt i Indien och Persien, där man förbrukar ett berg av det, och det betingar ett högt pris i Malabar, Narsinga och Cambay [platser i Indien]. De skepp från Malacka och Java som kommer dit på grund av detta, bringar som bytesobjekt bilor, yxor, knivar, svärd, kläder från Cambay och Pulicat [i Indien], porslin, färgad korall, tenn, kvicksilver, bly och andra handelsvaror, och mot detta lastar de i den ovannämnda sandeln, honung, vax, slavar och en smula peppar som finns i landet. ${ }^{22}$

Under 1500-talets lopp tog handeln med sandelträ fart tack vare den portugisiska aktiviteten. Sandel som i början av 1600-talet köptes upp på Timor kunde säljas i Sydkina för många gånger ursprungspriset. ${ }^{23}$ Trafiken underlättades av att Portugal hade flera baser längs Indiens kust och sedan 1550-talet hade satt sig fast i Macau i närheten av Kanton - en besittning de obrutet skulle behålla fram till 1999. Den bör också ha underlättats av att de små furstendömena saknade möjlighet eller vilja att avvisa de främmande sjöfararna. ${ }^{24}$ Ön var dessutom inte påverkad av islam, vilket betydde att dominikanska missionärer ostört kunde sprida sitt budskap i början av 1600-talet. ${ }^{25}$ Efter att först ha haft sitt lokala högkvarter på den lilla ön Solor norr om Timor flyttade de lokala portugisiska bosättarna över till ön Flores år 1613, då de holländska rivalerna började bli allvarligt aggressiva. Efter att ha försvagat ett par av de mäktigaste timoresiska furstendömena genom väpnade expeditioner 1641-42 började de föra över sin verksamhet till Timor självt på 1650-talet. Vid det laget var dock bosättarna mer sydöstasiatiska än europeiska. Bristen på kvinnliga medföljare på resorna till Asien gjorde att den portugisiska menigheten i östliga farvatten endast kunde fortplanta sig genom gifte med lokala kvinnor. Den mestisbefolkning som uppkom i Solor, Flores och Timor kom att gå under namnen svarta portugiser eller topasser. ${ }^{26}$

På motsvarande sätt insåg VOC snabbt hur lukrativ handeln med sandelträ kunde vara. Deras flottstyrkor slog ut de flesta portugisiska utposterna i Sydöstasien mellan 1605 och 1641, och de gjorde även krigiska åtbörder åt timorhållet. Mirakulöst nog lyckades dock de portugisiska bosättarna hålla sig kvar på Timor och angränsande öar. VOC hade visserligen ofantligt överlägsna resurser men det hade också många järn i elden längs Asiens kustlinjer. Då kompaniet på allvar försökte ta itu med rivalerna på 1650-talet var det för sent. Topasserna hade skapat ett stabilt samfund med inflytande över stora delar av ön, och i tre militära drabbningar 1655-57 förödmjukades holländarna å det gruvligaste. ${ }^{27}$ VOC fick nöja sig med ett litet fort längst i väster med det förhoppningsfulla namnet Fort Concordia ('Endräkt").

22 C. C. F. M. Le Roux, 'De Elcono's tocht door den Timorarchipel met Magalhães' schip "Victoria"', i Feestbundel uitgegeven door het Koninklijk Bataviaasch Genootschap van kunsten en Wetenschappen, Vol. II. Weltevreden: Kolff \& Co. 1929, s. 42.

23 A. de Roever, De jacht op sandelhout: De VOC en de tweedeling van Timor in de zeventiende eeuw. Zutphen: Walburg Pers 2002, s. 155.

24 Sejarah daerah Nusa Tenggara Timur (Jakarta: Departemen Pendidikan dan Kebudayaan 1984), s. 30-32.

25 P. B. M. Biermann, 'Die alte Dominikanermission auf den Solorinseln', Zeitschrift für Missionswissenschaft 14 1924; A. T. de Matos, Timor Português, 1515-1769, s. 47-51.

26 C. R. Boxer, The Topasses of Timor. Amsterdam 1947.

27 de Roever, De jacht op sandelhout, s. 243-69, 352; A. B. de Sá [red.], Documentação para a história das missões do padroado português do Oriente Insulindia, Vol. V. Lisboa: Agencia Geral do Ultramar 1958, s. 425-431. 


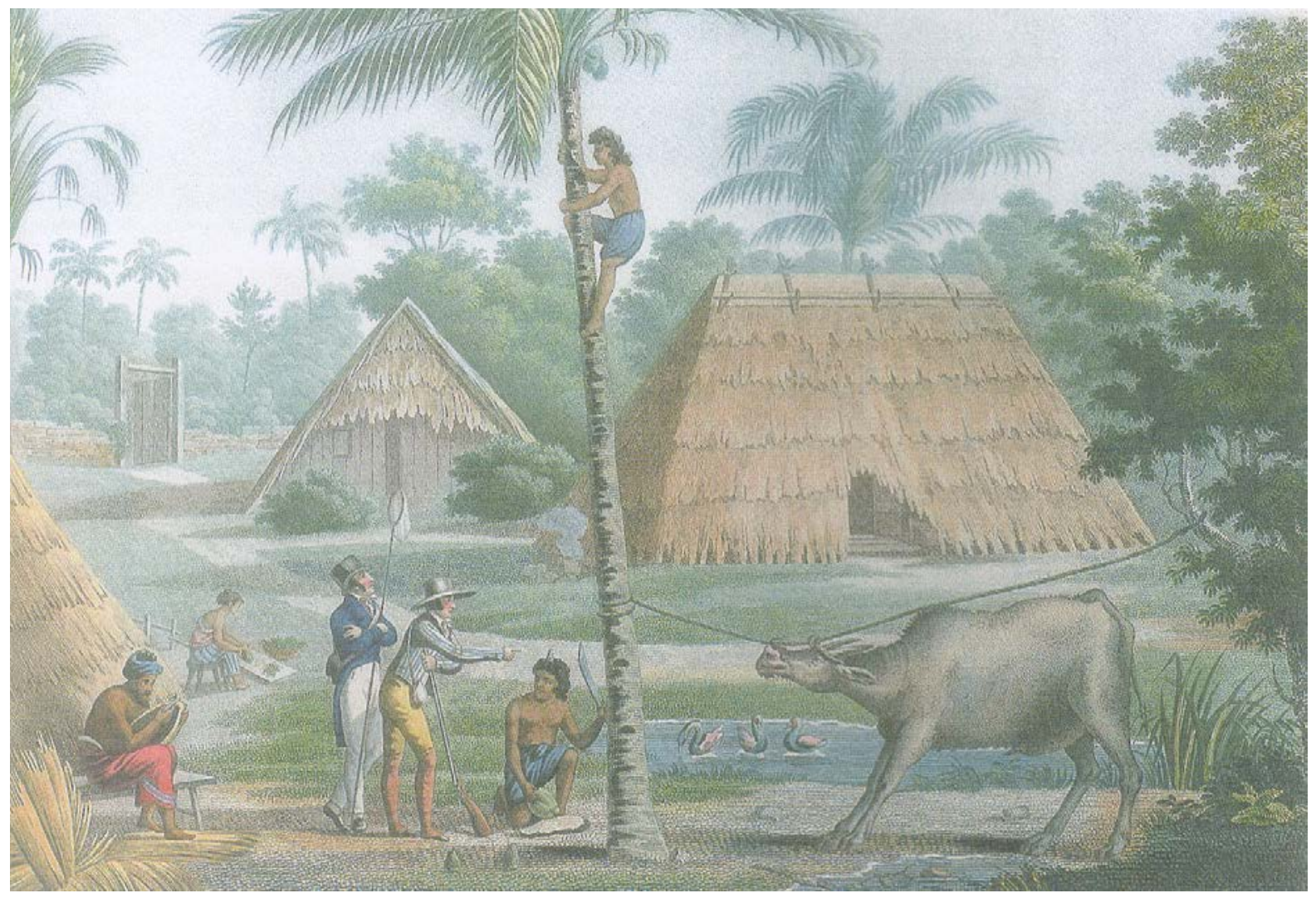

Lantlig scen från trakten av Kupang, från det franska besöket 1818.

Vid fortet växte en blygsam handelsort fram, Kupang. Ett fătal timoresiska furstar som fann för gott att ty sig till VOC slog sig ner i närheten av fortet med sina följeslagare. Öarna Rote, Sawu, Solor och Adonara, som låg i Timors närhet, erkände också kompaniet som sin överordnade allierade.

Tråkigt nog för holländarna fanns det inte mycket sandel att få tag på, eftersom det mesta av ön med därtill hörande sandelbestånd hörde till Portugals inflytelsesfär; det var först efter mitten av 1700-talet som vi fick den ungefärliga uppdelning av ön i jämnstora sfärer som syns på dagens politiska karta. Holländska rapporter målade upp en nedslående ekonomisk bild av förhållandena. Orsaken till att man fann mödan värt att behålla Kupang, hette det, var att staden var en del av förbindelselinjerna mellan Batavia och de mer lukrativa besittningarna på kryddöarna. Därtill var det alltid en god sak att hålla uppsikt över de portugisiska rivalerna, även sedan fred officiellt hade slutits 1663. Man fick alltså göra det bästa av en dålig situation. En hyggligt intressant produkt var vax, eftersom det finns gott om bin på Timor. Lokalbefolkningen skrämde bort bina med rök, bröt upp boet och tog ut honungen och vaxet. Vaxet kokades och knådades till bollar om 600 gram som sedan tillhandahölls holländarna, som fann den timoresiska sorten vara av ovanligt bra kvalitet. ${ }^{28}$ Det rådde en sorts gåvoekonomi där de VOC-trogna furstarna levererade produkter och i utbyte fick moderna vapen och lyxvaror tillsända från Batavia.

28 J. D. Kruseman, Timor, opublicerat manuskript 1824, i Coll. G. J. C. Schneither, No. 131, Nationaal Archief, Haag. 
Här kom också slavar in som en handelsvara i brist på annat. Den svåröverskådliga politiska situationen på Timor, med tjogtals konkurrerande furstendömen, ledde till ständiga småkrig. De fångar som togs i striderna - som mer hade karaktären av överfall än verkliga sammandrabbningar - gick ett ovisst öde till mötes. Liksom på många håll i Sydöstasien förekom huvudjakt, förmodligen stimulerad genom den koloniala rivaliteten mellan holländare och portugiser. En besegrad fiende kunde mista sitt huvud, som sedan användes i noga föreskrivna ritualer och festiviteter. ${ }^{29}$ Besegrade grupper kunde också helt enkelt infogas i den segrande furstens välde, som kuvade men inte förslavade undersåtar. Ett tredje alternativ var att de förvandlades till slavar, antingen för att tjäna stormän i deras hushåll eller för att säljas på slavmarknaden. Eftersom timoreserna själva inte var några sjöfarare eller professionella handelsmän måste långväga transporter skötas av andra grupper: européer, kineser eller sjöfarare från andra delar av arkipelagen.

Hur skaffade då holländarna i Kupang slavar för eget bruk eller för att föra till Batavia? Svaret finner vi i de rapporter som befälhavarna på Fort Concordia skickade till sina överordnade ett par gånger om året. Lokala småkrig var här en viktig källa. Den tättbefolkade ön Rote strax väster om Timor hade på 1650-talet så mycket som sjutton små furstendömen (med lokal terminologi nusak). En del av dem var benägna att hålla sig till VOC medan andra föredrog att satsa på portugiserna. År 1654 bredde de pro-holländska furstarna ut sin makt och intog ett av de pro-portugisiska landområdena med kompaniets stöd. Vid det tillfället togs 142 personer till fånga och omhändertogs av holländarna i Kupang. Dessa presenterades stolt för myndigheterna i Batavia som ett bevis på att besittningarna i Timorregionen i alla fall producerade några nyttigheter - 142 slavar var i själva verket inget oväsentligt antal vid denna tid med dess blygsamma stadspopulationer. I Batavia var man dock mindre förtjust. En skriven kommentar konstaterade grinigt att "de är föga begärliga, vare sig här eller i Banda [en utpost i Moluckerna] på grund av sitt onda och mordiska sinnelag". ${ }^{30}$ Roteneserna var alltså alltför obändiga och ovilliga att acceptera sitt slavöde för att kompaniet skulle känna sig komfortabelt med dem.

Icke desto mindre fortgick slavjakten under de följande åren. Profithungern tycks snart ha segrat över alla betänkligheter om slavarnas sinnelag, speciellt med tanke på de ekonomiska förluster kompaniet varje år gjorde på utposten i Kupang. År 1660 intervenerade den holländske militären Johan Truytman med en europeisk flottstyrka på Rote där en del furstar fortfarande var ovilliga att underkasta sig VOC. En av dem, fursten (manek) av Dengka, tvingades att "underteckna" ett avtal med Truytman. Eftersom skrivkonsten inte var känd i denna del av Sydöstasien betydde det att han satte ett kryss på ett papper vars text han sak-

29 H. G. Schulte Nordholt, The Political System of the Atoni of Timor. The Hague: M. Nijhoff 1971, s. 345-353 ; J. B. Pelon, Description de Timor Occidental et des îles sous domination hollandaise (17711778). Paris: Cahier d'Archipel No. 34 2002, s. 37. Vid överfall på byar tycks det ha varit vanligt att de vuxna dödades medan pojkar och flickor blev slavar åt meo, de framstående krigarna; se A. McWilliam, Paths of Origin, Gates of Life: A Study of Place and Precedence in Southwest Timor. Leiden: KITLV Press 2002, s. 141-142. Kruseman, Timor, tror att situationen förvärrades efter det att kolonialmakten gjorde slut på den öppna slavhandeln 1818, eftersom de ekonomiska motiven att låta besegrade fiender behålla livet minskade.

30 de Roever, De jacht op sandelhout, s. 257. 
nade möjlighet att kontrollera. Enligt den holländska tolkningen skulle fursten leverera 100 slavar som skulle föras till det pålitligt pro-holländska furstendömet Termanu och därifrån skeppas över till Kupang. Varifrån slavarna skulle tas var hans huvudvärk. Snart därpå klagade befälhavaren på Fort Concordia över att fursten struntat $\mathrm{i}$ att fullgöra sina förpliktelser. Trots upprepade påstötningar hade holländarna inte sett mer än tre män, sex kvinnor och fyra barn. $^{31}$

En annan furste på Rote, Sode av Lole, hade lovat att ta fast ett antal slavar som tillhört en avrättad person och överlämna dem till kompaniet. Sode samlade in 80-90 personer men ångrade sig sedan och släppte dem åter fria med orden ”Skulle jag leverera mina vänner som slavar till holländarna? Hellre gåve jag dem [...] människor att äta." ${ }^{32}$ Fortsättningen på historien berättas bäst av befälhavaren Hugo Cuylenburgh i ett officiellt brev till Batavia.

Eftersom skepps- och krigsfolket måste ligga overksamma [vid Kupang] under några dagar, lät jag församla dem och förehöll för dem att det inte var effektivt. Då Kung Sode hade bedragit kommissarien på ett falskt och skälmaktigt sätt [...] borde man anfalla honom med vapen i hand för att sätta skräck i denna nation [roteneserna]. Därpå beslöts att man skulle ta hela härsmakten, bestående av 936 man, nämligen 307 soldater och matroser och 629 sonbaier, amabier och kupangeser [timoresiska allierade] som skulle hemsöka Lole [...] Den 18 oktober [1660] marscherade vi dit. Den 19 överföll vi dem i dagbräckningen. Vi högg ner ungefär 500 utan att själva förlora en man, Gud vare tack, utan med blott två sårade. Förstörandet av orten Lole har injagat skräck över hela Rote, och bringat dem att fullfölja den kontrakterade leveransen av slavar. Den 2 januari 1661 kom kung Tullia [av Dengka] hit med de resterande, så att det Ädla Kompaniet fick sina 100 slavar från Dengka. ${ }^{33}$

Liknande saker utspelades åtskilliga gånger i Timorområdet. Grupper som motsatte sig de holländska kraven kunde utsättas för eld och svärd och se delar av populationen föras bort $i$ slaveri. Det bör dock märkas att holländarna på Timor vid det citerade tillfället var ovanligt manstarka; ofta var VOC:s resurser att handskas med trilskande allierade i regionen mycket begränsade. ${ }^{34}$ Den uppenbara cynism som framträder i exemplet ovan bör heller inte tolkas så att holländarna var nämnvärt värre än andra europeiska eller asiatiska grupper (en stor del av kompaniets personal var för övrigt inga etniska holländare utan även t.ex. svenskar). Slaveriet var helt enkelt en så självklar företeelse att knappast någon moraliserade över den. Portugiserna var av samma skrot och korn. Då de utvidgade sina domäner till de östra kusttrakterna av Timor kring 1668-1670 tog de tusentals slavar samtidigt som de brände och förödde områden som nekade dem sin lydnad. ${ }^{35}$

31 VOC 1236, f. 506, Nationaal Archief, Haag.

32 VOC 1236, f. 507, Nationaal Archief, Haag.

33 Ibid.

34 Årsrapporterna från slutet av 1600-talet visar att den anställda personalen vid Fort Concordia vid denna tid bara utgjorde något 50-tal man. Därtill kom personer vars tjänst hos VOC avslutats och som slog sig ner som borgare i Kupang. Antalet invånare i staden under 1600- och 1700-talen är inte helt klarlagt. Enligt en studie från 1836 bestod de direkta holländska undersåtarna på Timor då av 800 vita och färgade hushåll, 200 kinesiska hushåll, samt 1200 slavar. De flesta bodde i staden Kupang. Se J. D. Kruseman, 'Beschrijving van Timor', Oosterling 2 1836, s. 10-11.

35 W. Ph. Coolhaas [red.], Generale Missiven van governeurs-generaal en raden aan Heeren XVII der Verenigde Oostindische Compagnie, Vol. III. Haag: M. Nijhoff 1968, s. 681, 929-931. 


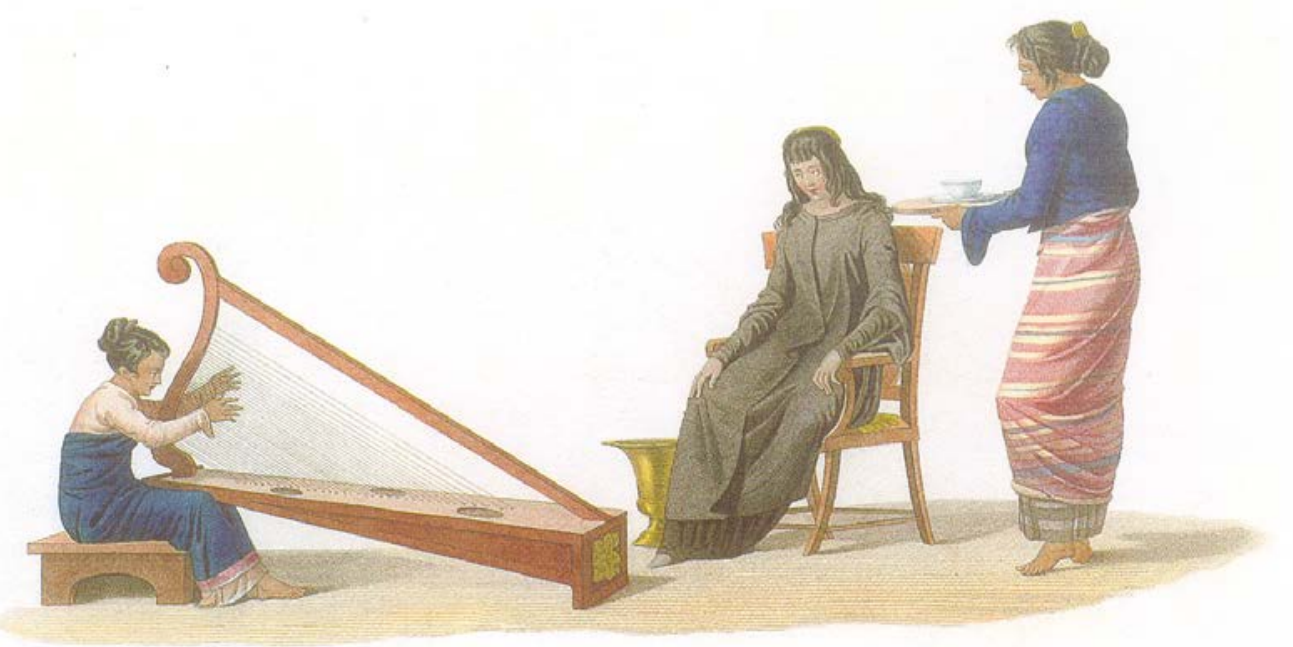

En överklasskvinna av inhemsk eller blandad härkomst serveras te av en tjänarinna, under det att en annan underhåller sin matmor med harpospel. Illustration från Freycinets franska expedition som besökte Kupang på Timor år 1818.

Inom såväl den holländska som den portugisiska sfären såg på motsvarande sätt de inhemska grupperna slaveriet som en naturlig källa till rikedom då handeln med sandelträ sviktade. Eftersom sandel är en halvparasitisk växt, måste den växa i anslutning till värdträd. ${ }^{36}$ Den ekologiska kunskapen om detta fanns emellertid inte hos människor vid denna tid, och försök att plantera ny sandel då de äldre bestånden utarmats var därför dömda att misslyckas. Detta gjorde slavhandeln till ett alternativ. En fransk sjöfarare som besökte Östtimor 1772 berättade att befolkningens enda kommers bestod $\mathrm{i}$ att de levererade slavar till det sjöfarande folket makassareser från ön Sulawesi, och i utbyte fick sablar och kriser (dolkar). ${ }^{37}$

Det fanns andra sätt än krig att förvärva slavar på. De lokala furstarna var visserligen inga maktfullkomliga despoter, eftersom deras resurser att övervaka undersåtarna var begränsade och de måste verka inom den komplicerade traditionella maktstrukturen ${ }^{38}$ Likväl hade de möjligheter att agera mot personer som misshagade dem. En initierad rapport från 1778 berättar att härskarna till följd av animositet eller vidskepelse kunde fă för sig att anklaga individer för svart magi, tjuvnad eller äktenskapsbrott. Utan vidare formaliteter förklarades den olycklige som slav, och med honom alla hans familjemedlemmar. Härskaren lade beslag på det familjen ägde. Han lade stor möda på att sälja de förslavade människorna till främlingar för att ha dem ur vägen. Ibland kunde dock offrens vänner friköpa dem genom att betala en viss mängd guld, en metall som finns naturligt i begränsade mängder på ön. De timoreser

36 de Roever, De jacht op sandelhout, s. 328.

37 F. E. de Rosily, 'Un mémoire inédit de F. E. Rosily sur l'île de Timor' Archipel 23 1982, s. 100. Av portugisiska dokument framgår dock att handeln med slavar på Östtimor var föga betydelsefull, i varje fall ur europeisk synvinkel.

38 Den intrikata förkoloniala strukturen i de timoresiska furstendömena finns beskriven i stor detalj i Schulte Nordholt, The Political System of the Atoni of Timor; T. Therik, Wehali, the Female Land: Traditions of a Timorese Ritual Centre. ANU: Pandanus Books 2004; samt A. D. M. Parera, Sejarah pemerintahan raja-raja Timor. Jakarta: Pustaka Sinar Harapan 1994. 
som bodde i närheten av det holländska fortet hade vanan att ge slavarna till befälhavaren som en del i den ovannämnda gåvoekonomin. ${ }^{39}$

Holländarna själva föregick med tvivelaktigt exempel i sina affärer med timoresiska klienter. VOC:s huvudkontor i Batavia skickade år 1756 kommissionären Johannes Andreas Paravicini till Kupang för att skriva nya kontrakt med lokalfurstarna och hålla räfst och rättarting med kompaniets personal. Paravicini betecknade de senare som en odifferentierad samling drinkare och skrävlare och fann att den vildvuxna utposten präglades av brist på disciplin, ekonomisk oreda och övervåld mot lokalbefolkningen. ${ }^{40}$ Bland de värsta våldsverkarna var en viss David Schrijver om vilken edsvurna vittnesmål hade ett och annat att berätta.

År 1752 hade VOC och deras timoresiska allierade anfallit och krossat ett uppstudsigt furstendöme vid namn Amarasi. Vid det tillfället lät David Schrijver sina följeslagare ta 40 personer som fångar - som krigsfångar var de rättslösa och kunde utan vidare säljas som slavar. Nu hade emellertid en av de holländska allierade, fursten av Amabi, vänner och anhöriga bland de tillfångatagna. Han kom därför överens med Schrijver om att friköpa fångarna mot 80 personer av furstens eget folk. När fursten avled några år senare var skulden till Schrijver fortfarande inte helt betalad. Den otålige holländaren började nu gå aggressivt tillväga och höll den avlidnes familjemedlemmar som fångar för att pressa fram slavarna. Dessutom vände han sig mot Willem, regent i grannriket Taebenu, som var svåger till den döde fursten; svågrar var i det timoresiska samhället starkt förpliktigade att samverka. Utan vidare diskussion lät han självsvåldigt sina män plocka upp tolv människor i byn Bikolan som tillhörde Willem. Vid tillfället var Willem upptagen på annat håll med att leda arbetet att fälla sandelträn för VOC:s räkning, och hade alltså inte möjlighet att hindra tilltaget. Då han kom tillbaka från skogen och fick höra vad som hänt begav han sig genast till Kupang för att få tillbaka de bortrövade undersåtarna. Till sin sorg fann han att David Schrijver hade tagit dem med sig på ett skepp destinerat Batavia, där de skulle säljas som slavar. ${ }^{41}$

Paravicini tyckte att den våldsamme kolonialtjänstemannen hade gått för långt och rekommenderade ett kännbart straff. Att på det sättet trakassera furstliga personer var mycket skadligt för VOC:s position och prestige på ön. Rådet i Batavia, som sedermera diskuterade saken, fann dock ingen anledning att agera utan lät David Schrijver gå fri. Emellertid dödades han fem år senare tillsammans med flera andra holländare då de överfölls av de portugisiska topasserna under en expedition. Att Paravicinis egen humanism inte ska överdrivas visas av att han lät anfalla och förslava befolkningen i det lilla furstendömet Landu på ön Rote som visat sig motsträvigt mot kompaniet. ${ }^{42}$

Slavar anskaffades alltså genom krig och genom att människor beslagtogs av inhemska och koloniala myndigheter. Nästa fråga gäller hur slavarna kom till användning, och framför allt hur de behandlades. Den franske upptäcktsresanden Baudin, som besökte Timor 1801

39 Pelon, Description de Timor Occidental, s. 33.

40 J. A. van der Chijs, 'Koepang omstreeks 1750', Tijdschrift voor Indische Taal-, Land- en Volkenkunde 18 1872, s. 209-227. Paravicini rapporterade bland annat att befälhavaren på fortet beordrade en soldat att rengöra sitt vapen men fick det brutala svaret "Gör det själv"!

41 VOC 2941, f. 116-7, 137-9, Nationaal Archief, Haag.

42 H. Fiedler, 'Hans Albrecht v. Plüskow als Oberhaupt von Timor: Geschichte eines kleinen Kontors der V.C.O. 1758-1761', Deutsche Wacht 17 1931; van der Chijs, 'Koepang omstreeks 1750'. 
och 1803, skriver: "Slavar är också en del av kompaniets kommers. Timor och de angränsande öarna förser det regelmässigt med två hundra per år, vilka transporteras till Batavia. Det rör sig inte om andra än välskapta barn som är ägnade för den lokala personalens och rikemännens nöjen." ${ }^{43}$ Orden för tankarna till sexuellt utnyttjande av barn, men av andra källor vet vi att även vuxna personer fördes bort. Deras öden i Batavia och andra koloniala poster återstår att studera, men man får anta att de i likhet med andra grupper användes som husslavar, hantverkare, affärsbiträden, hamnarbetare och liknande. Hantverksskickliga slavar hämtades från Indien fram till omkring 1660, men därefter föredrog VOC att använda sig av indonesiska grupper. ${ }^{44}$

I de årliga rapporterna (Generale missiven) finns ibland statistiska uppgifter om det antal slavar som fördes från Kupang till Batavia, vilka tyder på att utförseln inte var demografiskt signifikant. År 1704 var antalet utskeppade slavar 20, 1705 23, 1706 14, och så vidare. ${ }^{45}$ Då myndigheterna i Batavia år 1758 beordrade att skicka 200 slavar till Bandaöarna i nordöst, där de skulle arbeta på kryddplanteringarna, visade det sig omöjligt att leverera mer än 30; beklagligtvis pågick för tillfället inga krig där man kunde ha tagit fångar. Baudins siffra på 200 utfraktade slavar per år är förmodligen tilltagen i överkant. Därtill kommer att slavar (eller frigivna slavar) tidvis också fördes till Timor. Framför allt gäller det folk från Bali, vilka ansågs vara goda och pålitliga soldater. ${ }^{46}$ Då VOC:s politiska åtaganden på Timor ökade i mitten av 1700-talet opererade myndigheterna hellre med balineser än med timoresiska allierade, vilka betraktades som opålitliga i stridssituationer.

I Kupang med omland fanns annars tre kategorier av ofria: de som lydde direkt under kompaniet, de som hörde till stadens borgare samt de som stod under etniska timoreser. Kompanislavarna bodde i Fort Concordia där ett speciellt slavhus var inrättat. Fortet var ett illa underhållet komplex som låg på en klippig höjd vid kusten. ${ }^{47}$ De som hamnade här var lekamligen svaga krakar som hade ratats av stadens borgare och inte heller dög att skeppas till Batavia - på sätt och vis hade de tur eftersom slavtransporter ofta var förbundna med hög dödlighet. I mitten av 1700-talet uppgick de till ett femtiotal personer, tärda människor vars uppgift var att betjäna soldaterna på fortet. I allmänhet tycks de ha kommit från de kringliggande öarna snarare än från Timor självt. ${ }^{48}$

För att föda kompanislavar och andra ofria i Kupang hade VOC ett mycket speciellt arrangemang. På den närbelägna ön Rote växte gott om lontarpalmer, och dessa träd kunde tappas på en näringsrik sockerjuice, gula. Roteneserna själva omtalades ibland, halvt skämt-

43 Pelon, Description de Timor Occidental, s. 13, not.

44 Rodriguez, The Historical Encyclopedia of World Slavery, Vol. I, s. 366.

45 W. Ph. Coolhaas, Generale Missiven van governeurs-generaal en raden aan Heeren XVII der Verenigde Oostindische Compagnie, Vol. VI. Haag: M. Nijhoff 1976, s. 299-300, 354, 423.

46 Fiedler, 'Hans Albrecht v. Plüskow als Oberhaupt von Timor', s. 33-35.

47 Ingenting finns kvar av det gamla fortet idag. På platsen ligger numera en förläggning för ABRI, de indonesiska väpnade styrkorna.

48 Fiedler, 'Hans Albrecht v. Plüskow als Oberhaupt von Timor', s. 27. I dokument från slutet av 1600-talet nämns att kompanislavarna ibland företog tyngre arbetsuppgifter som kalkbränning. Det är därför möjligt att "kvaliteten” på deras arbetsförmåga sjönk fram till mitten av 1700-talet. 
samt, som "det icke-ätande folket" - de drack sin förnämsta föda! ${ }^{49}$ Rotenesiska småfurstar seglade regelbundet den korta sträckan till Kupang där de sålde krus med gula till kolonialmakten. Denna gula gavs sedan som en god men något ensidig kost till stadens ofria arbetskraft. Även ris fanns i deras kosthåll, ett dyrbart livsmedel på Timor som man fick importera från andra delar av övärlden. ${ }^{50}$

I början av VOC:s tillvaro på Timor fanns också en kategori av vad man närmast kan kalla sexslavar. Det fanns få europeiska kvinnor i Sydöstasien. Kvinnor av blandad härkomst var vanligare men var till en början inte tillgängliga i den holländska sfären på Timor. De soldater och hantverkare som sändes till Kupang på 1650- och 1660-talen hade alltså få möjligheter till umgänge med kvinnor. I perioder då disciplinen slappnade ledde det nästan oundvikligen till incidenter. Den ovannämnde befälhavaren Hugo Cuylenburgh tillät sina mannar att ta sig konkubiner som ibland hölls innanför försvarsanläggningarna. Då VOC nedkämpade ett nytt uppror på Rote 1663 passade Cuylenburgh själv på att lägga sig till med dottern till en lokal storman vid namn Sebille. Kvinnorna på Rote har ljusare skinn och ett mer malajiskt utseende än de mörka timoresiskorna, och har traditionellt varit eftertraktade av såväl europeiska som timoresiska män. Cuylenburgh "gifte" sig nu med Sebilles dotter efter rotenesisk sed, vilket alltså inte var giltigt enligt holländsk lag. Sebille själv visade sig framför fortet och begärde förtvivlat att hans dotter och andra släktingar skulle återbördas. Då holländarna inte brydde sig om att reagera seglade han rasande tillbaka till Rote där han vandrade runt bland byarna och manade till kamp mot de förhatliga vita männen och deras medlöpare. ${ }^{51}$

Då Cuylenburghs efterträdare Anthony Hurt ankom till Timor 1665 fylldes han av kalvinistisk indignation över förhållandena och avfattade en frän anklagelseskrift mot företrädaren:

Tiden i fortet tillbringades, som det berättades och delvis kom för mina ögon, med dryckenskap och onyttigt tidsfördriv som herr Cuylenburgh dag efter dag kunde bestå. Man var så otyglade att det föreföll honom besvärligt att sätta en fot utanför fortet. Det är sant att hans impotens därvid har hindrat honom något, men detta kommer sig knappast av något annat än av ett dylikt leverne. ${ }^{52}$

Sebilles dotter var heller inte sin lastbare herre trogen, och när Cuylenburgh fann att han var bedragen lät han kedja henne. En kolonialtjänsteman skickades sedermera över till Rote för att undersöka de oroligheter som nu bubblade på ön. Av alla de lokala regenterna var det emellertid bara en som specifikt omtalade Sebille som medskyldig till jäsningen, "så att saken inte är klar, utan man skulle storligen betänka vad han [Cuylenburgh] skulle anklagas för, om inte hans otukt lett honom till cunnilingus med den ovannämnde Sebilles dotter.' ${ }^{53}$

49 J. J. Fox, Harvest of the Palm; Ecological Change in Eastern Indonesia. Cambridge, Mass.: Harvard University Press 1977.

50 Ris och majs var sedan 1600-talet de viktigaste grödorna på Timor, men de knappa förhållandena gjorde att lokalbefolkningen var ovillig att leverera det till VOC, vars ris därför måste skeppas ända från Java.

51 VOC 1252, f. 1226, Nationaal Archief, Haag.

52 VOC 1252, f. 1227, Nationaal Archief, Haag.

53 “...bijaldien sijne ontugt hem niet gevoert hadt tot Conoulingus met de voorsz. Sebilles dochter." VOC 1252, f. 1228, Nationaal Archief, Haag. 
Det fanns alltså gränser även för VOC. Medan slaveriet sågs som en naturlig del av kompaniets ekonomi var Cuylenburghs sexuella egenheter - möjligen betingade av hans påstådda impotens - tillräckligt klandervärda för att betinga en officiell skrivelse som slutligen nådde huvudsätet i Amsterdam. Den nye befälhavaren Anthony Hurt lät fördriva soldaternas konkubiner utanför vaktposternas ställningar ehuru kirurgen, timmermannen och smeden bestörta försäkrade honom om att de fått tillåtelse av Cuylenburgh att ta sig en mö. Vad som slutligen skedde med Sebilles dotter förmäler inte dokumenten.

Portugisiska dokument skiljer mellan två typer av ofria på Timor. Den ena sorten, lutuhum, var lantarbetare som odlade landet och vallade boskapen för furstarnas räkning och inte kunde säljas. Den andra sorten var de egentliga slavarna; krigsfångar och personer som inte kunnat betala böter, vilka utförde tyngre arbetsuppgifter. ${ }^{54}$ Det här svarar till den grovuppdelning av ett mjukare och hårdare slaveri som vi kan skönja i Sydöstasien i övrigt. Holländska dokument är inte lika tydliga med en sådan uppdelning. Man talade i västra Timor om ate vilket väl snarast motsvarade den lägre kategorin i den portugisiska sfären. De var, tillsammans med guld och boskap, den främsta rikedomsmarkören för de VOC-allierade stormännen. Normalt förefaller de ha använts som tjänare i hushållen och i förekommande fall lantarbetare. Deras numerär var betydande, fast deras andel i förhållande till den fria befolkningen är svår att ange. ${ }^{55}$ Det är möjligt att de slavar som lydde under borgare och infödda i Kupangområdet var mer utsatta för godtycke än deras motsvarigheter i Batavia. Kupang utvecklades till en multietnisk samfällighet där européer, kineser, mestiser, soloreser, roteneser, sawuneser och timoreser levde i varandras närhet. Vissa timoreser antog kristendomen och deras ättlingar inlemmades i stadssamfundet. I en sådan urban miljö blev slavar sannolikt mer av en handelsvara än i det förkoloniala systemet. Samtidigt kom timoresisk sedvanerätt att spela roll i olika sammanhang, även i behandlingen av slavar.

En afton i december 1692 gick den aristokratiska timoresiskan Susanna upp till fortet och uppsökte den holländske befälhavaren Willem Moerman. Susanna och hennes man var kristna och inlemmade i den koloniala samfälligheten. Hon berättade att soloresen Wuring och hennes släkting Taly hade bundit en slavinna som tillhörde henne ett stycke utanför Kupang och slagit henne så illa att hon avled. Moerman gav sig verkligen tid att undersöka fallet; Susanna var dotter till en regent och en person av viss status. Följande dag lät han förhöra inblandade personer varför slavinnan blivit så grymt behandlad. Susannas bror svarade i de bägge våldsverkarnas ställe att de inte tänkt döda kvinnan utan bara tukta henne eftersom hon varit ohörsam och försökt rymma. "Då hon nu dött hade ingen förlorat någonting utom ägarinnan som själv tuktat [låtit tukta] henne, och deras lands seder gav dem fullkomlig makt över sina ofrias liv och död". 56

Moerman, som tycks ha haft mer ansvarskänsla än många av sina kollegor, nöjde sig inte med det utan lät kalla samman de allierade furstarna till ett möte i fortet påföljande dag. Moerman frågade de församlade vilket straff detta dråp på en slav borde föra med sig. Furstarna svarade då att detta över huvud taget inte straffades bland dem, utan var och en månde leva

54 de Matos, Timor Português, 1515-1769, s. 190.

55 McWilliam, Paths of Origin, Gates of Life, s. 141; Pelon, Description de Timor Occidental, s. 22.

56 VOC 1531, sub 5 december 1692, Nationaal Archief, Haag. 


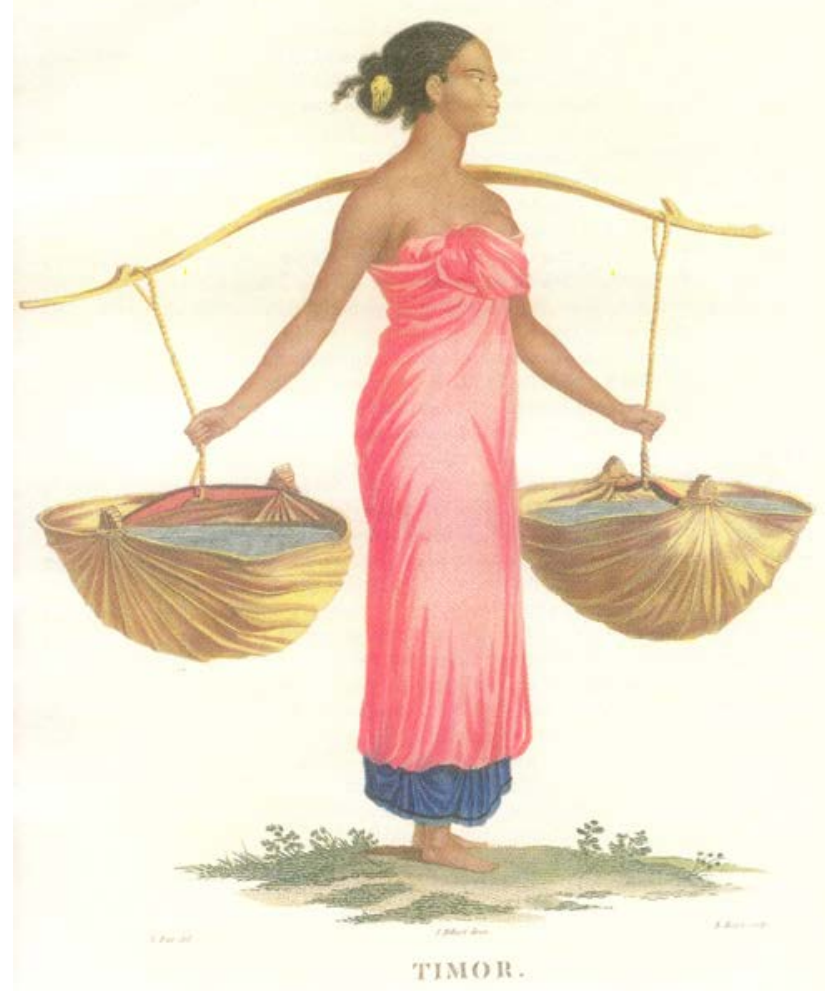

En timoresisk flicka bär vatten i behållare tillverkade av blad. Fransk illustration från 1801-03.

med sina slavar som det behagade honom. Detta gällde för övrigt inte bara slavar utan också det gemena folket; varje temukung (hövding) kunde bringa sina underlydande liv eller död, utan att det blev rättssak. Furstarna berättade vältaligt för Moerman om flera liknande fall där de även själva varit handgripligen aktiva. En regent i furstendömet Amabi hade bara några dagar tidigare slagit ihjäl en kvinna från ett grannrike som gift sig med en av hans underlydande men sedan falskeligen rymt sin kos. De församlade framhöll att tidigare befälhavare aldrig hade tagit upp sådana här saker i rådet. Dödsmisshandeln, försäkrade de, skulle inte komma att orsaka någon som helst uppståndelse bland den inhemska befolkningen.

Moerman måste alltså motvilligt släppa våldsverkarna Wuring och Taly som kom undan med en rejäl åthutning. Furstarna uppmanades att inte utsätta människor för så grymma straff utan i fortsättningen tillrättavisa dem med goda ord och diskretion. Moerman kommenterade i fortets logg att myndigheterna i Batavia hade uppmanat kolonialtjänstemännen i Kupang att lägga sig i lokalbefolkningens angelägenheter så lite som möjligt. Det var därför bäst att låta saken glida undan eftersom regenterna var invanda med detta grymma men hävdvunna bruk. Dessutom var våldsverkarna och Susannas släktingar "hedningar" (det vill säga animister), vilket inte gjorde saken lättare. ${ }^{57}$

Det är möjligt att furstarna överdrev sin egen makt över undersåtarnas liv och död, eftersom de hade intresse av att hålla VOC borta från sina inre angelägenheter. Det som lyser fram ur exemplet är emellertid kompaniets oförmåga eller ovilja att ta itu med det som med

57 VOC 1531, sub 6 december 1692, Nationaal Archief, Haag. 
varje normal måttstock måste betecknas som övervåld och brutalitet. Ett bidragande skäl torde vara att ett stort mått av brutalitet accepterades av VOC självt, inte bara mot slavar utan också mot de anställda vita. I noteringarna från slutet av 1600-talet finner man flera fall där holländare avvek från Fort Concordia utan lov och därför dömdes till hårda fysiska straff. En sattes på en vass trähäst i hettan, en pryglades tre dagar i följd, och så vidare. Ett fall från 1694 låter oss ana något av den hårda verklighet som kunde möta även slavar som lydde direkt under holländarna.

På morgonen den 3 maj detta år fördes en illa tilltygad flicka på 12-13 år innanför fortets murar. Flickan var slavinna och hette Raja. Tillsammans med sin moder Kapy, som var född på ön Sawu, hade hon rymt för en dryg vecka sedan men nu åter infångats. De båda slavinnorna, mor och dotter, ställdes inför Willem Moerman. Denne lade märke till att bägge två hade sår på buken, som om de blivit stuckna av något. Kapy sade att de fallit omkull och skadat sig på vassa trädgrenar då de flydde. Moerman lät sitt folk förbinda dem. Nästa dag dog emellertid den unga Raja och fortets kirurg konstaterade att hon hade fått ett dödligt sår som gick djupt in i kroppen. Moerman fattade nu misstankar och började förhöra såväl modern som de rotenesiska slavjägare som sett kvinnorna vid rymningen. ${ }^{58}$ Steg för steg rullades den tragiska historien upp.

På natten mellan 22 och 23 april hade sju slavar och slavinnor rymt från Kupang. Den direkta anledningen till rymningen nämns inte, men en av ägarna, Floris Jansz, var en ökänd buse som inte ens drog sig för att attackera aristokrater. ${ }^{59}$ Holländarna sände genast ut slavjägare som vid niotiden på morgonen hann upp rymlingarna i vildmarken utanför Kupang. Slavarna spred sig i vild flykt i skogen för att försöka skaka av sig förföljarna. Kapy och Raja blev dock efter och slavjägarna närmade sig för att ta fast dem. Skräcken för vad deras herre skulle göra med dem då de förts tillbaka tog överhanden och Raja bad sin moder att göra slut på henne. Kapy stack "på djävulens ingivelse" den kniv hon bar på sig i dotterns buk och stack sig därpå själv. De bägge kvinnorna föll till marken inför ögonen på slavjägarna. Dessa greps av fasa över det makabra skådespelet och löpte iväg utan att undersöka såren. Då de kom tillbaka till fortet och sina boplatser skaffade de förstärkning och gick ånyo bort till skådeplatsen för dramat. De såg blod på marken men kunde inte upptäcka några kroppar och återvände därför tomhänta till Kupang. Kvinnorna hade var för sig vaknat till sans och släpat sig bort. Kapy gömde sig i hålor och klippor under två-tre dagar tills hon blev funnen av några timoreser som förde henne till Fort Concordia. ${ }^{60}$ Raja blev också funnen och överlämnades döende till kompaniet. Modern återhämtade sig från sitt självförvållade sår, men hennes olyckor var inte slut med detta. Det beslöts att hon skulle sändas till Batavia där saken närmare skulle granskas av myndigheterna. Hennes slutliga öde är inte känt. ${ }^{61}$

Händelsen var förmodligen ovanlig eftersom den fått stort utrymme i källmaterialet, med utförliga vittnesmål och rapporter. Vad tragedin vittnar om är emellertid den väldiga skräck för repressalier som slavar som begått felsteg hade anledning att hysa. Så grymma straff var

58 VOC 1553, sub 3, 4, 5, 6 maj 1694, Nationaal Archief, Haag.

59 VOC 1673, f. 72-73, Nationaal Archief, Haag.

60 VOC 1553, odat. vittnesmål av Touw Savo, Toewa och Kapy, Nationaal Archief, Haag.

61 VOC 1553, rapport sub dato 21 maj 1694, Nationaal Archief, Haag. 
att vänta för en rymning - även för minderåriga - att självmord var ett alternativ. Då Kapy var född på Sawu hade hon sannolikt tagits som slav i samband med krigshandlingar och var därför ur holländsk (och timoresisk) synvinkel närmast rättslös. Samtidigt visar exemplet att förhållandevis plikttrogna kolonialtjänstemän som Moerman ville undersöka allvarliga incidenter på ett byråkratiskt korrekt sätt. Det slaveri som VOC stod för må ha varit mer opersonligt än den traditionella sydöstasiatiska varianten, men kolonialmakten stod trots allt för en uppsättning fasta regler som i bästa fall åtlyddes även i avlägsna utposter som Kupang.

Fanns då inga försonande drag i det slavsystem som frodades i mötet mellan tidig kolonialism och timoresiska grupper? Jo, trots allt var det ingen självklarhet att en människas slavstatus skulle förbli permanent. Det var möjligt att göra en blygsam men ändå social klättring inom ramen för systemet. I den portugisiska sfären kunde slavar friges av sina herrar eller då husbondefamiljen dog ut. De hamnade då per automatik i samma klass som sina gamla ägare (detta gällde dock inte för slavar som tillhörde furstefamiljerna). ${ }^{6}$ Frigivning omtalas också i den holländska sfären och hade gärna karaktären av ekonomiska transaktioner. Ett annat rättsfall från 1694 berättar att rotenesen Baffy Horry förälskade sig i slavinnan Kilo Anak som tillhörde en timoresisk prinsessa i Kupangområdet. Kilo Anak lämnades till Baffy Horry för att bli hans äkta hustru, men som gengäld måste han ge två slavar till prinsessan. $\mathrm{Nu}$ ville emellertid olyckan att Baffy Horry dog innan han hunnit leverera mer än en slav. På grund av det olägliga dödsfallet krävdes Kilo Anak tillbaka av prinsessans familj och tvingades att åter leva som ofri hos fursten över helongstammen. ${ }^{63}$ I Kupang omtalas sedan slutet av 1600-talet också en grupp människor kallade mardijkers (av malajiskans mardahika eller merdeka, "fri”). I övärlden i övrigt var mardijkers vanligen sydöstasiater eller indier som upptagit det portugisiska språket och delar av kulturen och för det mesta härstammade från frigivna slavar. ${ }^{64}$ På Timor var begreppet mer flytande och syftade snarast på personer vars förfäder kommit till Kupang som slavar men sedermera blivit frigivna och ofta döpta. Mardijkers kom att utgöra en väl sammanhållen grupp som tjänade som soldater och ibland rentav hotade VOC:s auktoritet i den holländska sfären. ${ }^{65}$

Man kan också ifrågasätta om förhållandena överallt i regionen var så dåliga som de mer dramatiska exempel som refererats kan ge intryck av. Man får komma ihåg att källmaterialet trots allt ger en selektiv bild av vardagen för 1600- och 1700-talets människor. Ibland lyses scenen upp av någon detaljerad rapport eller ett rättsligt material, men vanligen framstår gruppen av slavar inom VOC:s synfält som anonym och odifferentierad. Den brittiske antropologen Henry Forbes reste på 1880-talet i Portugisiska Timor, som knappast var mer välordnat eller centraliserat än den holländska sfären varit på 1600- och 1700-talen: "Hövdingar och datos [underregenter] håller sig alla med slavar, men de behandlas på intet vis hårdhänt. Deras frigivning kan när som helst köpas genom att man betalar en fast summa [...] Slavar tycks dock sällan kräva sin frihet. Livet är inte så rosenskimrande att det får dem att vilja 62 de Matos, Timor Português, 1515-1769, s. 191.

63 VOC 1553, vittnesmål sub dato 21 maj 1694, Nationaal Archief, Haag.

64 L. Blussé, Strange Company; Chinese Settlers, Mestizo Women and the Dutch in VOC Batavia. Dordrecht: Foris 1988, s. 165.

65 A. Haga, 'De mardijkers van Timor', Tijdschrift voor Taal-, Land- en Volkenkunde 27 1882, s. 191-294. 


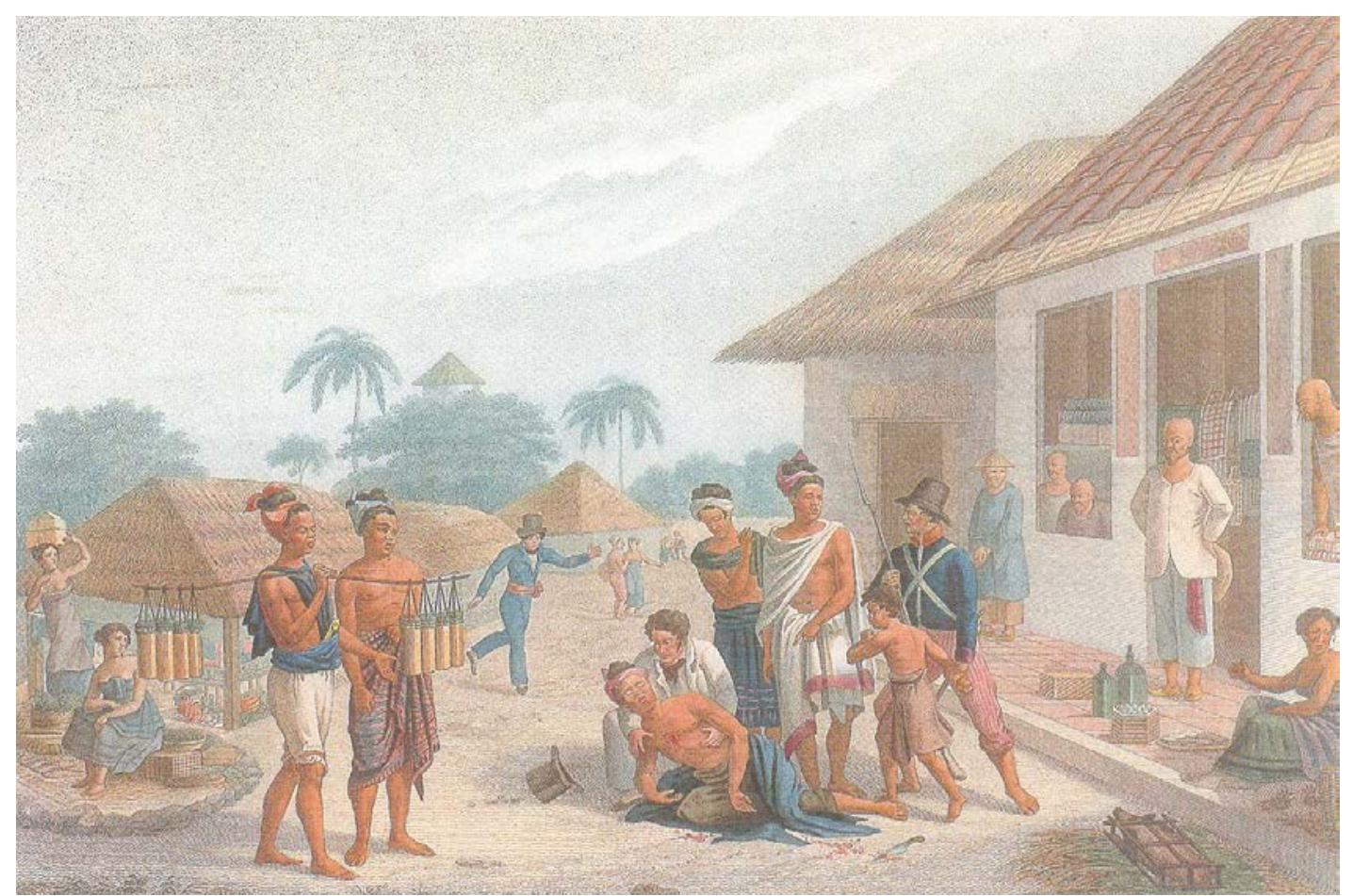

Dramatisk scen från Kupang 1818. En gosse tycks ha tillfogat en vuxen man ett dolkstygn. Man kan notera den etniska blandningen i staden, med timoreser, kineser och vita.

ändra sina säkra ransoner och milda behandling för det osäkrare utfallet av det lika hårda, om inte hårdare, arbetet med sina egna händer." ${ }^{66}$ Forbes var en tillfällig besökare och hans studie säger kanske inte hela sanningen, men klart är att bilden av det timoresiska slaveriet är långtifrån entydig.

Liksom på andra håll i Europa började kritiska röster mot slaveriets princip göra sig gällande i Nederländerna i slutet av 1700-talet. Upplysningens ideal och de liberala principer som så småningom bröt in talade entydigt för ett avskaffande av den juridiska ofriheten. Ur ekonomisk synvinkel var det ett klumpigt och föråldrat system. Några år efter britternas förbud mot slavhandel följde Nederländerna deras exempel, år 1818, även om avsteg mot förbudet förekom långt senare. Slaveriet som sådant var dock alltför fast rotat i de koloniala samhällena i Sydamerika och Sydöstasien för att tillräcklig idealism och målmedvetenhet skulle kunna uppbådas för att avskaffa det. Den holländska abolitionismen kom därför att bli en ganska senfärdig rörelse. Britterna slog an tonen genom att avskaffa slaveriet i sina domäner 1833-1838 och andra europeiska länder följde efter under de följande decennierna - Sverige år 1847. I holländska Ostindien, det som skulle bli Indonesien, lät avskaffandet vänta på sig ända till 1859, för övrigt samma år som Nederländerna och Portugal efter två seklers rivalitet kom överens om hur de skulle dela upp Timor mellan sig. 4800 slavar friköptes genom myndigheternas försorg. Det relativt blygsamma antalet visar hur improduktivt och omodernt slavsystemet hunnit bli - så sent som 1814 fanns det 27000 ofria under holländsk

66 H. O. Forbes, 'On some of the tribes of the Island of Timor', Journal of the Anthropological Institute 13 1884, s. 417. 
domvärjo. ${ }^{67}$ Någon revolutionär social förändring blev heller inte följden. I lokalsamhällen där den direkta europeiska närvaron var föga märkbar fanns människor med slavliknande status kvar fram till relativt modern tid - till exempel på ön Solor norr om Timor. ${ }^{68}$

För att sammanfatta så kan slaveriet på Timor under VOC-eran ses som en inte otypisk skärva av det komplex som fanns i Sydöstasien vid denna tid. En ofrihet som byggde på ett personligt förhållande herre-underlydande förekom sida vid sida med ett hårdare och mer opersonligt slaveri. I den holländska sfären i Västtimor utvecklades under loppet av tre sekler (1653-1949) en samverkan mellan koloniala och inhemska grupper som innebar en ömsesidig påverkan. Holländarna verkade till en början under ganska små och utsatta omständigheter på den lilla utposten, och de föredrog att i stort sett spela med de lokala förhållandena. De inhemska ledarna, däremot, såg sin prestige stärkas i vissa avseenden genom samarbetet med VOC, med befogenheter som inte helt motsvarades av furstendömenas traditionella struktur. Det är möjligt att kulturmötet på det sättet bidrog till att göra slaveriet relativt hårdare. Slavar blev en handelsvara; de kunde fraktas fram och tillbaka på ett sätt som saknade motsvarighet i det inhemska systemet, och det beskydd och de skjutvapen som de allierade erhöll av VOC gav nya möjligheter att hålla grupper av människor under kontroll.

De psykologiska följderna av slaverisystemet yttrade sig i en djup misstänksamhet mot den vite mannen som tycktes sakna samvetsbetänkligheter inför hanteringen med mänskligt kött och blod. Detta fick den franske upptäcktsresanden Péron erfara vid sitt besök i Kupang 1801. Péron bekantade sig med en aristokratisk familj som till följd av europeisk girighet kommit på obestånd och nu drog sig fram som blygsamma fiskare. Speciellt blev han god vän med Cornelis, den yngste sonen i familjen och frågade om han inte skulle ha lust att slå följe med Péron på färden tillbaka till Europa. Cornelis sade först ivrigt ja, men snart infann sig en mörk tanke i hans huvud. Han kratsade pedagogiskt ihop högar av sand i olika storlekar för att illustrera för Péron vad han menade. Med uttrycksfulla ord och gester förklarade han sedan på malajiska det predikament som skulle kunna bli följden av att han reste, och hans ord kan bilda slutvinjett för denna studie:

I Kupang är mannen Péron vän med Cornélis; men i landet Frankrike kommer en man och säger till dig: 'Sälj denne röde [brune] man till mig', och han visar upp en så här stor penningsumma för dig [pekade på den minsta sandhögen]. Du svarar: 'Denne röde man är vän till mannen Péron'. Du ger samma svar till dem som kommer och erbjuder dig dessa andra sandhögar; men slutligen ger någon dig en penningsumma lika stor som den sista sandhögen, och du säger: 'Må den röde mannen bli slav'. Således ser jag inte vidare av mannen Péron. Man tvingar mig att arbeta i elände och den stackars Cornelis, som är långt borta från sin fader Neas och sin broder Pone, dör av sorg och sjukdom... ${ }^{69}$

67 Rodriguez, The Historical Encyclopedia of World Slavery, Vol. I, s. 366-367; R. Pélissier, Timor en guerre: Le crocodile et les portugais (1847-1913). France: Orgeval 1996, s. 40; H. J. de Graaf, Geschiedenis van Indonesië. 's Gravenhage: Van Hoeve 1949, s. 419.

68 Siti Dasi, 's-Hertogenbosch, personlig kommunikation, oktober 2006.

69 F. Péron, Voyage de decouvertes aux terres Australes, Vol. I. Paris: L'Imprimerie Impériale 1807, s. $158-159$. 